\title{
Working
}

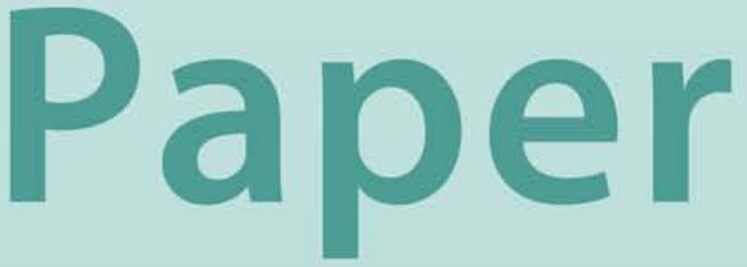


Determinants of Bank Credit in Emerging Market Economies

Kai Guo and Vahram Stepanyan 


\title{
IMF Working Paper
}

European Department

\section{Determinants of Bank Credit in Emerging Market Economies ${ }^{1}$ \\ Prepared by Kai Guo and Vahram Stepanyan}

Authorized for distribution by Albert Jaeger

March 2011

\begin{abstract}
We examine changes in bank credit across a wide range of emerging market economies during the last decade. The rich time-series and cross-section information allows us to draw broader lessons compared to many existing researches, which focus on a specific set of emerging market economies or on shorter time periods. Our results show that domestic and foreign funding contribute positively and symmetrically to credit growth. The results also indicate that stronger economic growth leads to higher credit growth, and high inflation, while increasing nominal credit, is detrimental to real credit growth. We also find that loose monetary conditions, either domestic or global, result in more credit, and that the health of the banking sector also matters. Finally, we discuss some policy lessons.
\end{abstract}

JEL Classification Numbers: G21, E44, E51

Keywords: bank credit, emerging markets

Authors’ E-Mail Addresses: kguo@imf.org, vstepanyan@imf.org

\section{This Working Paper should not be reported as representing the views of the IMF.} The views expressed in this Working Paper are those of the author(s) and do not necessarily represent those of the IMF or IMF policy. Working Papers describe research in progress by the author(s) and are published to elicit comments and to further debate.

\footnotetext{
${ }^{1}$ This paper has benefited from comments by participants in the seminar organized in July 2010 by the Southeastern Europe Network of the European Department. We also thank other departments and Czech National Bank representatives for helpful comments on the final draft.
} 


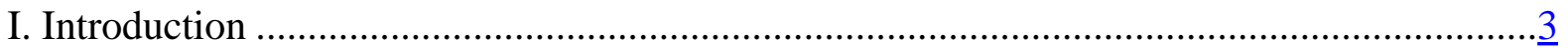

II. Stylized Facts and Literature Review...................................................................

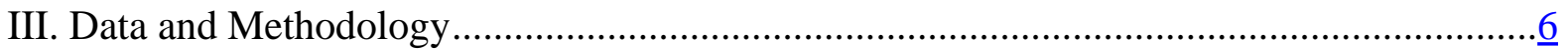

IV. Estimation Results and Robustness Checks ..........................................................

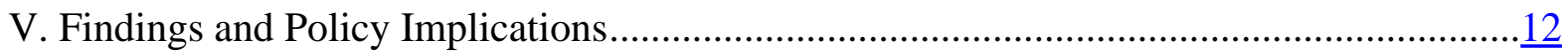

Tables

1. Data Series and Sources................................................................................ $\frac{7}{9}$

2. Regression Results Under Benchmark Specification .............................................. $\underline{9}$

3. Regression Results Under Alternative Specifications ............................................11

4. Regression Results Under Alternative Specifications with Time Dummies ...............12

Figures

1. Average Credit Growth Before and After the Crisis ...............................................

2. Decomposition of Credit Growth in EU EMEs ...............................................

3. Decomposition of Credit Growth in other European EMEs ...................................14

4. Decomposition of Credit Growth in Middle East and Africa EMEs .......................... $\underline{14}$

5. Decomposition of Credit Growth in Asia EMEs .............................................. 15

6. Decomposition of Credit Growth in Central America EMEs ..................................16

7. Decomposition of Credit Growth in South America EMEs ......................................16

Appendix



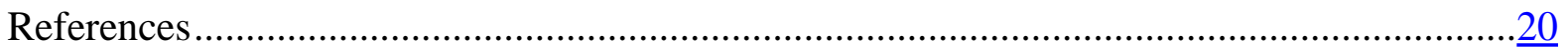




\section{INTRODUCTION}

Determinants of bank credit in emerging market economies (EMEs) have recently been a subject of a growing body of empirical work, particularly in light of the boom-bust cycles some EMEs experienced before and after the global crisis.

What determines credit growth in EMEs? What were the main drivers of pre-crisis credit booms in some countries and what has contributed to the post-crisis busts? Are booms and busts completely independent events or are they caused by the same underlying factors? Why were there considerable regional differences in terms of credit growth before and after the crisis? What can we learn from these vastly different experiences?

This paper tries to shed light on these questions by investigating data from a large panel of EMEs over the last decade, covering both pre-crisis and post-crisis periods. We identified both demand and supply factors that affect credit growth, with a focus on the supply side. More specifically, domestic deposit growth and non-resident liability growth contribute positively and symmetrically to credit growth. Stronger economic growth increases demand for credit and leads to higher credit growth. High inflation, while increasing nominal credit, is detrimental to real credit growth. Loose monetary conditions, either domestic or global, result in more credit, and a healthy banking sector tends to extend more credit than an unhealthy one. We conducted numerous robustness checks, and our results appear to be robust under various specifications and sample periods. Furthermore, our results show that the same set of factors can explain both time-series and cross-sectional variations in credit growth: namely, the vastly different experiences of credit growth before and after the crisis and across regions could to a large extent be explained by changes in these underlying factors. Interesting policy lessons can also be learned from these findings.

The rest of this paper is organized as follows: section II presents stylized facts on bank credit developments and a literature overview on the subject; section III describes data and methodology; section IV presents estimation results and robustness checks; and section V draws some policy implications and concludes.

\section{STYLIZED FACTS AND LITERATURE REVIEW}

The experience of credit growth before the crisis was vastly different across countries and regions. During the pre-crisis period, bank credit grew on average at around 24 percent in our sample, with the maximum growth rate at 59 percent and the minimum rate at 6 percent. The post-crisis period data shows a much lower average annual growth of 8 percent, with a maximum rate at 32 percent and a minimum rate at -3 percent.

Figure 1 presents bank credit developments in the EMEs.We divided them into six regional groups. As one can see, during the post-crisis period EMEs in all regions experienced a substantial slowdown in credit growth with quite a few of them registering a decline in credit. 
Figure 1. Average Credit Growth Before and After the Crisis
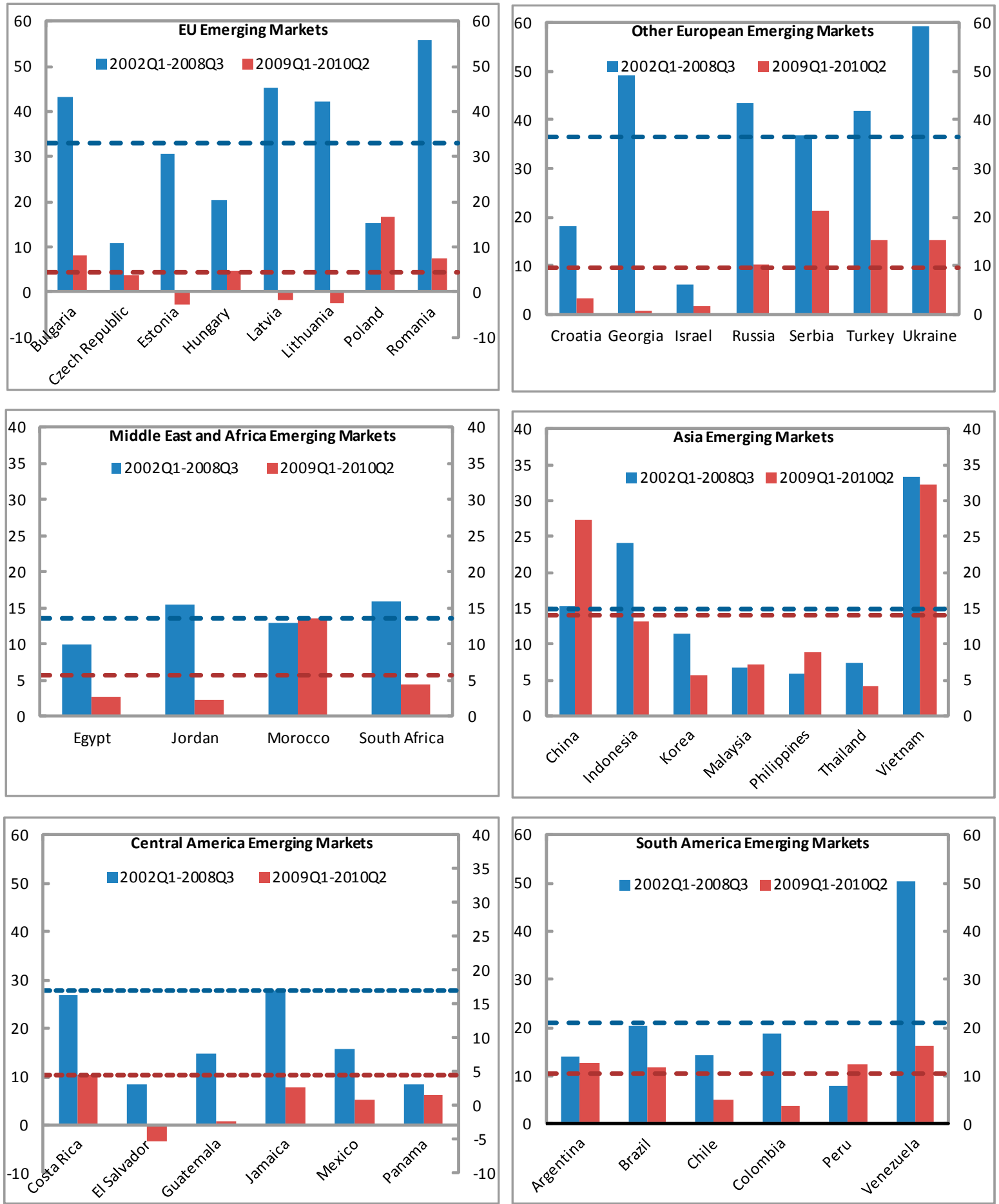

Source: Authors' calculations.

1/ Averages of four-quarter growth rates of nominal credit.

2/Horizontal blue and red lines present group averages for pre-crisis and post-crisis periods, respectively. 3/ Although the Czech Republic and Korea have been reclassified into the advanced economy group, we decided to include them in our sample as they were EMEs during part of the period of our analysis. 4/We grouped Israel with the other European EMEs for purely analytical reasons. 
The sharpest slowdown took place in the European EMEs, which also had the strongest credit expansion before the global financial crisis. In the pre-crisis period, bank credit in EU EMEs expanded at an average rate of 33 percent. In the post-crisis period, credit expansion in these economies slowed down to 4 percent on average with three countries (the Baltic States) registering a decline in credit. Other European EMEs experienced an even higher pre-crisis rate of credit expansion-36 percent on average-while their post-crisis credit growth slowed down to 10 percent.

Our sample of EMEs in the Middle East and Africa region covers only four countries where credit expanded at a rate of 14 percent on average in the pre-crisis period. Post-crisis credit growth slowed down sharply in Egypt, Jordan, and South Africa. Morocco, with an almost stable post-crisis credit expansion rate, is one of the outliers in the overall sample.

Asian EMEs contain most of the outliers in our sample. While in Indonesia, Korea, and Thailand bank credit registered notable slowdown in the post-crisis period, it continued to expand at an even stronger pace in China, Malaysia, and Philippines. In Vietnam, post-crisis credit expansion was stable at a high rate of around 30 percent.

Both Central American and South American EMEs experienced strong pre-crisis credit expansion-17 percent and 21 percent on average, respectively. Post-crisis bank credit in Central American economies slowed down to 5 percent on average while the South American economies continued to register solid growth in bank credit, albeit at a much slower rate-10 percent on average.

There is a growing literature on the determinants of bank credit in EMEs, particularly in light of the developments after the collapse of Lehman Brothers. Many EMEs, especially European EMEs, experienced a precipitous fall in banking credit after a long credit boom. Others - for example, EMEs in Latin America-were less affected as far as credit growth is concerned. Some Asian countries, notably China, even staged significant credit expansions during and after the crisis.

Takáts (2010) concluded that supply shock was the main determinant of slowdown in crossborder lending to emerging markets during the crisis. Bakker and Gulde (2010) found that external factors (bad luck) were the main reason for credit booms and busts in new EU members. Aisen and Franken (2010) documented that pre-crisis boom and slowdown in partner countries were the main determinants of credit growth during the crisis. Kamil and Rai (2010) argued that the sources of funding (external vs. internal) mattered during the crisis for credit growth, with countries that rely more on external funding suffering the most. Barajas, Chami, Espinoza, and Hesse (2010) found that bank-level fundamentalscapitalization and loan quality-helped to explain differences in credit growth across Middle Eastern and North African countries.

This paper contributes to the literature on several fronts. First, we tried to cover the universe of EMEs as long as data are available. This allows us to utilize available information from all EMEs and ensure that the results are consistent across countries. This is particularly important for any cross-country lessons that may be drawn from the empirical results. In fact, 
our results suggest that the same set of underlying factors helps explain a significant portion of cross-country variations in credit change, suggesting there are common factors behind seemingly different experiences of bank credit growth among EMEs. Second, we cover a longer period (2002Q1-2010Q1) than most papers did, in order to capture the full boom and bust cycle. This helps to avoid the problem of estimation results being driven only by the boom or the bust. It also helps to indentify the underlying factors that contribute to the boom and bust cycle and therefore could offer useful information regarding how to lower the risk of such cycles in the future. Third, we take into account both demand and supply side factors, with a focus on the supply side.

\section{DATA AND MeThodology}

In our analysis we employ quarterly data series which are sourced from the following IMF databases: International Financial Statistics (IFS), World Economic Outlook (WEO), and Global Financial Stability Report (GFSR). The data spans a period from the first quarter of 2001 to the second quarter of 2010 and covers 38 countries: ${ }^{2}$ Argentina, Brazil, Bulgaria, Chile, China, Colombia, Costa Rica, Croatia, Czech Republic, Egypt, El Salvador, Estonia, Georgia, Guatemala, Hungary, Indonesia, Israel, Jamaica, Jordan, Korea, Latvia, Lithuania, Malaysia, Mexico, Morocco, Panama, Peru, Philippines, Poland, Romania, Russia, Serbia, South Africa, Thailand, Turkey, Ukraine, Venezuela, and Vietnam. ${ }^{3}$

Our analysis focuses on the following variables: banking sector private credit (dependent variable), ${ }^{4}$ banking sector foreign liabilities, ${ }^{5}$ banking sector domestic deposits, real GDP, inflation, deposit rate (as a proxy for the monetary condition), exchange rate, US federal funds rate, US M2 and non-performing loan ratio. Table 1 below presents the specific series and sources of the data we used in our analysis.

\footnotetext{
${ }^{2}$ Our initial sample consisted of more than 50 EMEs covered by the Fund's Vulnerability Exercise for Emerging Markets, but due to data limitations, we had to reduce the final sample to 38 countries.

${ }^{3}$ Although the Czech Republic and Korea have been reclassified into the advanced economy group, we decided to include them in our sample as they were EMEs during part of the period of our analysis. We grouped Israel with the other European EMEs for purely analytical reasons.

${ }^{4}$ We recognize that in some EMEs cross-border lending may play a substantial role in the overall credit to private sector; however, lack of data on cross-border lending does not allow accounting for this factor.

${ }^{5}$ For the purposes of this paper, banking sector foreign liabilities and non-resident liabilities or foreign borrowings are interchangeable.
} 
Table 1. Data series and sources

\begin{tabular}{lll}
\hline \multicolumn{1}{c}{ Variable } & \multicolumn{1}{c}{ Descriptor } & Database/Source \\
\hline Private credit & Claims on private/other sectors & IFTS \\
Foreign liabilities & Liabilities to non-residents/Foreign liabilities & IFTS \\
Domestic deposits & $\begin{array}{l}\text { Transferable/demand deposits; } \\
\text { savings deposits }\end{array}$ & IFTS \\
Inflation & Consumer prices & IFTS \\
Real GDP & GDP, constant prices/GDP VOL. & WEO/IFTS \\
Deposit rate & Deposit rate & IFTS \\
Exchange rate & Market rate & IFTS \\
Non-performing loans & Non-performing loans & GFSR \\
US Federal funds rate & Federal funds rate & US Federal Reserve \\
US M2 & M2 & US Federal Reserve
\end{tabular}

Due to data availability, some countries are missing data either at the start of the sample or at the end of sample. As a result, the panel is not balanced.

The benchmark specification of our regression, that broadly follows the literature on the subject, is as follows:

$$
\begin{aligned}
& \text { Credit Growth } h_{\mathrm{i}, \mathrm{t}} \\
& =\beta_{0}+\beta_{1}\left(\text { Shdepo }_{\mathrm{i}, \mathrm{t}-4} \times \text { Deposit Growth }_{\mathrm{i}, \mathrm{t}}\right) \\
& +\beta_{2}\left(\text { Shforeignlia }_{\mathrm{i}, \mathrm{t}-4} \times \text { Non }- \text { resident Liability Growth } h_{\mathrm{i}, \mathrm{t}}\right)+\beta_{3} \pi_{\mathrm{i}, \mathrm{t}} \\
& +\beta_{4} G_{\mathrm{i}, \mathrm{t}-1}+\beta_{5} \text { Deposit rate }_{i, t-1}+\beta_{5} \text { Fed Fund Rate Change } e_{i, t}+F E_{i} \\
& +\epsilon_{i, t}
\end{aligned}
$$

The dependent variable is growth rate of credit to private sector (Credit Growth $\left.{ }_{i, t}\right) .{ }^{6}$ The explanatory variables are:

Growth rate of deposits (Deposit Growth $h_{i, t}$ ). This variable is weighted by the share of deposits in total credit to the private sector four quarters ago (Shdepo $i, t-4$ ) to control for the overall importance of domestic deposits as a funding source. One would expect that higher deposit growth would lead to more credit growth as banks would have more loanable funds. ${ }^{7}$

Growth rate of non-resident liabilities (Non-resident Liability Growth ${ }_{i t}$ ). Again, this variable is weighted by the share of liabilities to non-residents in total credit to private sector four quarters ago (Shforeignlia ${ }_{i, t-4}$ ) to control for the overall importance of foreign borrowings as a

\footnotetext{
${ }^{6}$ Unless otherwise specified, all growth rates and changes are 4-quarter growth rates or 4-quarter differences.

${ }^{7}$ The assumption here is that more deposits lead to more credit.
} 
funding source. One would also expect this variable to have a positive impact on credit growth domestically.

Inflation $\left(\pi_{i t}\right)$. As nominal credit growth will in general be affected by inflation, we use inflation as a control variable. In addition, it could also inform us whether inflation is detrimental to real private credit growth or not. If the coefficient is less than 1 , then inflation will in fact decrease real private credit.

Lagged GDP growth $\left(G_{i, t-1}\right)$. GDP growth measures the overall health of the economy, and thereby can reflect the demand for credit. Higher GDP growth should translate into higher credit growth. We use lagged GDP growth in the regression in order to avoid the problem of reverse causality, namely high credit growth leading to higher GDP growth.

Lagged deposit rate (Deposit rate (D,t-1 $_{1}$ ). The deposit rate is used as a proxy for the overall monetary policy stance, as there are no well-defined monetary policy rates for many EMEs. Tighter monetary policy stance should result in slower credit growth. Because there usually will be a lag for monetary policy to take effect and there may also be reverse causality problem, we use lagged deposit rate instead.

Change in US federal fund rate (Fed Fund Rate Change $i_{i, t}$ ). In an increasingly interconnected world, it is plausible that the global environment may also have an effect on domestic credit growth in EMEs. We use change in US federal fund rate as a proxy for the global environment. The lower the fed fund rate, the looser the global liquidity conditions, and hence higher domestic credit growth. ${ }^{8}$

Because there may be other unobserved heterogeneities across countries that may affect credit growth, we controlled for country fixed effects in all our regressions.

\section{ESTIMATION RESULTS AND ROBUSTNESS CHECKS}

The estimation results of the benchmark specification are reported in the first column of Table 2. All coefficients are significant with expected signs. Both domestic deposits and liabilities to non-residents contribute positively to private credit growth. Moreover, the point estimates for these two variables are remarkably similar: both are around 0.5 . This seems to suggest that banks treat domestic funding and foreign funding symmetrically—-for every penny of additional funding, be it from domestic sources or foreign sources, half of that will be lent out to the private sector on average. Private credit also increases with inflation, but less than one to one, which implies that inflation in fact dampens real private credit growth. Higher GDP growth leads to more demand for credit and hence higher credit growth, while a higher deposit rate signals tighter monetary conditions and thereby less credit growth. Global

\footnotetext{
${ }^{8}$ We also used the difference between the Fed Fund rate and the rate that would be implied by the Taylor rule as an alternative measure of monetary conditions in the U.S. The results are broadly similar and are available from the authors upon request.
} 
environment also matters: the looser the monetary policy in the U.S., the higher the credit growth in EMEs.

We also ran the same regression over the pre-crisis period and the results are reported in the second column of Table 2.

Table 2. Regression Results under Benchmark Specification 1/

\begin{tabular}{lcc}
\hline & \multicolumn{2}{c}{ Private credit growth } \\
\cline { 2 - 3 } & $\begin{array}{c}\text { Full Sample } \\
(2002 \mathrm{Q} 1-2010 \mathrm{Q} 1)\end{array}$ & $\begin{array}{c}\text { Precrisis Sample } \\
\text { (2002Q1-2007Q4) }\end{array}$ \\
\hline Deposit growth & $0.508^{* * *}$ & $0.439^{* * *}$ \\
$\times$ deposit/credit & $(0.0531)$ & $(0.0807)$ \\
Non-res liab growth & $0.506^{* * *}$ & $0.551^{* * *}$ \\
$\times$ non-res liab/credit & $(0.121)$ & $(0.125)$ \\
Inflation & $0.367^{*}$ & 0.485 \\
& $(0.189)$ & $(0.328)$ \\
Lagged GDP growth & $0.763^{* * *}$ & $1.121^{* * *}$ \\
& $(0.281)$ & $(0.367)$ \\
Lagged deposit rate & $-0.414^{* *}$ & -0.380 \\
& $(0.159)$ & $(0.245)$ \\
Change in fed fund rate & $-0.548^{*}$ & 0.369 \\
Constant & $(0.285)$ & $(0.583)$ \\
Country fixed effect & $5.484^{* * *}$ & $3.215^{*}$ \\
Time fixed effect & $(1.317)$ & $(1.763)$ \\
Observations & $\mathrm{Y}$ & $\mathrm{Y}$ \\
Adjusted R-sq & $\mathrm{N}$ & $\mathrm{N}$ \\
& 1084 & 756 \\
\hline
\end{tabular}

Source: Authors' estimates.

1/ Standard errors are in parentheses and are clustered at country level.

There could be other factors that drive private credit growth in EMEs but are not included in our benchmark specification. We tried to control for these factors by running our regression with alternative specifications.

In certain EMEs - for example Croatia, Estonia, and Latvia-foreign currency loans may represent a significant portion of private credit, as emphasized in Rosenberg and Tirpák (2008). It is possible that private credit growth in terms of domestic currency simply reflects exchange rate movements rather than genuine growth of credit in these countries. Column 2 of Table 3 addresses this possibility by controlling for appreciation/depreciation of domestic currencies against the US dollar. ${ }^{9}$ Here, an increase in the exchange rate denotes depreciation of domestic currency. It is reassuring that the estimates for the primary variables we are

\footnotetext{
${ }^{9}$ We also tried bilateral exchange rates against the Euro. The point estimate remains positive and significant. However, the magnitude is much smaller. This may be reflecting the fact that the dollar remains the major currency in denominating foreign currency loans in many EMEs. The results using Euro exchange rate are available from the authors upon request.
} 
interested in remain broadly the same. In addition, the positive and significant sign for exchange rate confirms that private credit growth in terms of domestic currency does seem to pick up some valuation effect of foreign currency loans.

It is also plausible that the initial conditions may also matter for private credit growth. Countries at the initial stage of financial deepening may experience faster credit growth than countries that already had credit booms. We controlled for initial credit-to-GDP ratio to account for this possibility and the results are reported in column 3 of Table 3. Again, the coefficients for those primary variables are broadly the same. Although the credit-to-GDP ratio is not significant, the sign of the coefficient nevertheless makes sense - the higher the initial credit-to-GDP ratio, the lower the subsequent credit growth.

Several papers suggested that the health of banks may be an important determinant of credit growth. Column 4 of Table 3 reports the results after controlling for the initial NPL ratio. Consistent with findings in McGuire and Tarashev (2008), a less healthy banking sector tends to extend less credit to the private sector. But since we only have NPL data for a subset of countries, coefficients for some other variables become slightly different from the benchmark case.

Column 5 of Table 3 reports results by using US M2 growth rate as an alternative measure of US monetary conditions. The results remain broadly similar to the benchmark case. Columns 6 and 7 report results by controlling for several additional factors at the same time. Again, all estimates remain sensible.

In Table 4, we present all regressions of Table 3 using time dummies to control for potential cyclical effects that are not captured by the variables we included. Other than some minor differences, the main results in Table 3 hold up fairly well.

There may be a question on whether our results are primarily driven by the crisis period, which is not necessarily representative for normal times. To address this concern, we ran our regressions using only the pre-crisis sample (2001Q1-2007Q4). Appendix Tables 1 and 2 report these regressions which show that our results remain broadly intact. 
Table 3. Regression Results under Alternative Specifications 1/

\begin{tabular}{|c|c|c|c|c|c|c|c|}
\hline \multirow[b]{2}{*}{$\begin{array}{l}\text { Deposit growth } \\
\times \text { deposit/credit }\end{array}$} & \multicolumn{7}{|c|}{ Private credit growth (2002Q1-2010Q2) } \\
\hline & $\begin{array}{l}0.508^{* * *} \\
(0.0531)\end{array}$ & $\begin{array}{l}0.506^{* * *} \\
(0.0559)\end{array}$ & $\begin{array}{l}0.494^{* * *} \\
(0.0505)\end{array}$ & $\begin{array}{l}0.583^{* * *} \\
(0.0803)\end{array}$ & $\begin{array}{l}0.498 * * * \\
(0.0558)\end{array}$ & $\begin{array}{l}0.496 * * * \\
(0.0531)\end{array}$ & $\begin{array}{l}0.475^{* * *} \\
(0.0570)\end{array}$ \\
\hline $\begin{array}{l}\text { Non-res liab growth } \\
\times \text { non-res liab/credit }\end{array}$ & $\begin{array}{c}0.506^{* * *} \\
(0.121)\end{array}$ & $\begin{array}{c}0.510^{* * *} \\
(0.121)\end{array}$ & $\begin{array}{c}0.497 * * * \\
(0.125)\end{array}$ & $\begin{array}{l}0.394 * * \\
(0.147)\end{array}$ & $\begin{array}{c}0.502^{* * *} \\
(0.119)\end{array}$ & $\begin{array}{c}0.502^{* * *} \\
(0.125)\end{array}$ & $\begin{array}{c}0.450^{* * *} \\
(0.153)\end{array}$ \\
\hline Inflation & $\begin{array}{l}0.367^{*} \\
(0.189)\end{array}$ & $\begin{array}{l}0.313^{*} \\
(0.180)\end{array}$ & $\begin{array}{l}0.402^{*} \\
(0.211)\end{array}$ & $\begin{array}{c}0.289 \\
(0.205)\end{array}$ & $\begin{array}{l}0.388^{* *} \\
(0.182)\end{array}$ & $\begin{array}{l}0.341^{*} \\
(0.201)\end{array}$ & $\begin{array}{c}0.218 \\
(0.195)\end{array}$ \\
\hline Lagged GDP growth & $\begin{array}{c}0.763^{* * *} \\
(0.281)\end{array}$ & $\begin{array}{c}0.889 * * * \\
(0.270)\end{array}$ & $\begin{array}{l}0.729 * * \\
(0.298)\end{array}$ & $\begin{array}{c}0.738 * * * \\
(0.230)\end{array}$ & $\begin{array}{c}0.784^{* * *} \\
(0.273)\end{array}$ & $\begin{array}{c}0.860^{* * *} \\
(0.285)\end{array}$ & $\begin{array}{c}0.678^{* * *} \\
(0.219)\end{array}$ \\
\hline Lagged deposit rate & $\begin{array}{c}-0.414^{* *} \\
(0.159)\end{array}$ & $\begin{array}{c}-0.685^{* *} \\
(0.257)\end{array}$ & $\begin{array}{c}-0.438^{* * *} \\
(0.156)\end{array}$ & $\begin{array}{c}-0.934 * * * \\
(0.333)\end{array}$ & $\begin{array}{c}-0.497 * * * \\
(0.167)\end{array}$ & $\begin{array}{c}-0.699 * * * \\
(0.248)\end{array}$ & $\begin{array}{c}-0.953^{* * *} \\
(0.324)\end{array}$ \\
\hline Change in fed fund rate & $\begin{array}{l}-0.548^{*} \\
(0.285)\end{array}$ & $\begin{array}{l}-0.545^{*} \\
(0.279)\end{array}$ & $\begin{array}{l}-0.599 * \\
(0.300)\end{array}$ & $\begin{array}{l}-0.292 \\
(0.350)\end{array}$ & & $\begin{array}{l}-0.585^{*} \\
(0.295)\end{array}$ & $\begin{array}{l}-0.648 * \\
(0.379)\end{array}$ \\
\hline Change in exchange rate & & $\begin{array}{l}0.133^{* * *} \\
(0.0409)\end{array}$ & & & & $\begin{array}{l}0.131^{* * *} \\
(0.0419)\end{array}$ & $\begin{array}{l}0.167 * * * \\
(0.0561)\end{array}$ \\
\hline Lagged credit-to-GDP ratio & & & $\begin{array}{l}-0.0601 \\
(0.0581)\end{array}$ & & & $\begin{array}{l}-0.0471 \\
(0.0600)\end{array}$ & $\begin{array}{r}-0.361^{* * *} \\
(0.0968)\end{array}$ \\
\hline Lagged NPL ratio & & & & $\begin{array}{c}-1.035^{* * *} \\
(0.372)\end{array}$ & & & $\begin{array}{l}-0.773 * \\
(0.411)\end{array}$ \\
\hline US M2 growth & & & & & $\begin{array}{l}0.327 \\
(0.472)\end{array}$ & & \\
\hline Constant & $\begin{array}{c}5.484^{* * *} \\
(1.317)\end{array}$ & $\begin{array}{c}7.029 * * * \\
(2.067)\end{array}$ & $\begin{array}{l}8.992^{* * *} \\
(3.183)\end{array}$ & $\begin{array}{c}13.95^{* * *} \\
(3.621)\end{array}$ & $\begin{array}{l}-0.656 \\
(1.565)\end{array}$ & $\begin{array}{c}9.747^{* * *} \\
(3.137)\end{array}$ & $\begin{array}{c}35.83^{* * * *} \\
(7.653)\end{array}$ \\
\hline Country fixed effect & $\mathrm{Y}$ & $\mathrm{Y}$ & $\mathrm{Y}$ & $\mathrm{Y}$ & $\mathrm{Y}$ & $\mathrm{Y}$ & $\mathrm{Y}$ \\
\hline Time fixed effect & $\mathrm{N}$ & $\mathrm{N}$ & $\mathrm{N}$ & $\mathrm{N}$ & $\mathrm{N}$ & $\mathrm{N}$ & $\mathrm{N}$ \\
\hline Observations & 1084 & 1084 & 1084 & 567 & 1084 & 1084 & 567 \\
\hline Adjusted R-sq & 0.637 & 0.651 & 0.638 & 0.747 & 0.651 & 0.651 & 0.785 \\
\hline
\end{tabular}

Source: IMF staff estimate.

1/ Standard errors are in parentheses and are clustered at country level. 
Table 4. Regression Results under Alternative Specifications with Time Dummies 1/

\begin{tabular}{|c|c|c|c|c|c|c|c|}
\hline \multirow[b]{2}{*}{$\begin{array}{l}\text { Deposit growth } \\
\times \text { deposit/credit }\end{array}$} & \multicolumn{7}{|c|}{ Private credit growth (2002Q1-2010Q2) } \\
\hline & $\begin{array}{l}0.483^{* * *} \\
(0.0497)\end{array}$ & $\begin{array}{l}0.483 * * * \\
(0.0532)\end{array}$ & $\begin{array}{l}0.444^{* * *} \\
(0.0442)\end{array}$ & $\begin{array}{l}0.435^{* * *} \\
(0.0858)\end{array}$ & $\begin{array}{l}0.483^{* * *} \\
(0.0497)\end{array}$ & $\begin{array}{l}0.445 * * * \\
(0.0456)\end{array}$ & $\begin{array}{l}0.366 * * * \\
(0.0674)\end{array}$ \\
\hline $\begin{array}{l}\text { Non-res liab growth } \\
\times \text { non-res liab/credit }\end{array}$ & $\begin{array}{c}0.476 * * * \\
(0.115)\end{array}$ & $\begin{array}{c}0.469 * * * \\
(0.116)\end{array}$ & $\begin{array}{c}0.434^{* * *} \\
(0.122)\end{array}$ & $\begin{array}{c}0.391^{* * * *} \\
(0.129)\end{array}$ & $\begin{array}{c}0.476^{* * *} \\
(0.115)\end{array}$ & $\begin{array}{c}0.428 * * * \\
(0.123)\end{array}$ & $\begin{array}{c}0.412^{* * *} \\
(0.139)\end{array}$ \\
\hline Inflation & $\begin{array}{c}0.275 \\
(0.229)\end{array}$ & $\begin{array}{c}0.204 \\
(0.233)\end{array}$ & $\begin{array}{c}0.348 \\
(0.257)\end{array}$ & $\begin{array}{l}0.0262 \\
(0.232)\end{array}$ & $\begin{array}{c}0.275 \\
(0.229)\end{array}$ & $\begin{array}{c}0.277 \\
(0.259)\end{array}$ & $\begin{array}{c}-0.00961 \\
(0.213)\end{array}$ \\
\hline Lagged GDP growth & $\begin{array}{l}0.778 * * \\
(0.298)\end{array}$ & $\begin{array}{c}0.887^{* * *} \\
(0.301)\end{array}$ & $\begin{array}{l}0.720^{* *} \\
(0.315)\end{array}$ & $\begin{array}{c}0.281 \\
(0.184)\end{array}$ & $\begin{array}{l}0.778 * * \\
(0.298)\end{array}$ & $\begin{array}{l}0.827^{* *} \\
(0.320)\end{array}$ & $\begin{array}{c}0.258 \\
(0.186)\end{array}$ \\
\hline Lagged deposit rate & $\begin{array}{l}-0.351^{*} \\
(0.206)\end{array}$ & $\begin{array}{c}-0.567 * * \\
(0.279)\end{array}$ & $\begin{array}{l}-0.330 \\
(0.205)\end{array}$ & $\begin{array}{c}-1.709 * * * \\
(0.334)\end{array}$ & $\begin{array}{l}-0.351^{*} \\
(0.206)\end{array}$ & $\begin{array}{l}-0.542 * \\
(0.276)\end{array}$ & $\begin{array}{c}-1.565^{* * *} \\
(0.300)\end{array}$ \\
\hline Change in fed fund rate & $\begin{array}{l}-0.283 \\
(0.250)\end{array}$ & $\begin{array}{l}-0.379 \\
(0.262)\end{array}$ & $\begin{array}{c}-0.571^{* *} \\
(0.260)\end{array}$ & $\begin{array}{c}0.376 \\
(0.389)\end{array}$ & & $\begin{array}{l}-0.512^{*} \\
(0.261)\end{array}$ & $\begin{array}{l}-0.0475 \\
(0.430)\end{array}$ \\
\hline Change in exchange rate & & $\begin{array}{l}0.120^{* * *} \\
(0.0431)\end{array}$ & & & & $\begin{array}{l}0.118^{* *} \\
(0.0437)\end{array}$ & $\begin{array}{l}0.163^{* *} \\
(0.0747)\end{array}$ \\
\hline Lagged credit-to-GDP ratio & & & $\begin{array}{c}-0.185^{* * *} \\
(0.0658)\end{array}$ & & & $\begin{array}{l}-0.182^{* * *} \\
(0.0638)\end{array}$ & $\begin{array}{c}-0.326^{* * *} \\
(0.109)\end{array}$ \\
\hline Lagged NPL ratio & & & & $\begin{array}{c}-1.536 * * * \\
(0.360)\end{array}$ & & & $\begin{array}{c}-1.214^{* * * *} \\
(0.428)\end{array}$ \\
\hline US M2 growth & & & & & $\begin{array}{l}1.486^{* * *} \\
(0.255)\end{array}$ & & \\
\hline Constant & $\begin{array}{c}22.85^{* * *} \\
(2.346)\end{array}$ & $\begin{array}{c}23.90^{* * *} \\
(3.049)\end{array}$ & $\begin{array}{l}47.15^{* * *} \\
(8.239)\end{array}$ & $\begin{array}{c}22.61^{* * *} \\
(3.221)\end{array}$ & $\begin{array}{c}11.14^{* * *} \\
(2.324)\end{array}$ & $\begin{array}{c}48.29 * * * \\
(7.614)\end{array}$ & $\begin{array}{c}62.95^{* * *} \\
(15.47)\end{array}$ \\
\hline Country fixed effect & $\mathrm{Y}$ & $\mathrm{Y}$ & $\mathrm{Y}$ & $\mathrm{Y}$ & $\mathrm{Y}$ & $\mathrm{Y}$ & $\mathrm{Y}$ \\
\hline Time fixed effect & $\mathrm{Y}$ & $\mathrm{Y}$ & $\mathrm{Y}$ & $\mathrm{Y}$ & $\mathrm{Y}$ & $\mathrm{Y}$ & $\mathrm{Y}$ \\
\hline Observations & 1084 & 1084 & 1084 & 567 & 1084 & 1084 & 567 \\
\hline Adjusted R-sq & 0.637 & 0.651 & 0.638 & 0.747 & 0.651 & 0.651 & 0.785 \\
\hline
\end{tabular}

Source: IMF staff estimate.

1/ Standard errors are in parentheses and are clustered at country level.

\section{Findings ANd Policy Implications}

Our estimation results allow the decomposition of credit growth in both pre- and post-crisis periods, based on which we try to outline the impact of the crisis on the main determinants of bank credit in each country ${ }^{10}$. Then, based on the findings, we discuss certain policy implications.

\footnotetext{
${ }^{10}$ Specifically, we use the estimation results for the full sample presented in Table 2.
} 
First we look at the group of EU EMEs, which, along with others in Europe, have recorded the highest pre-crisis credit expansion. In this group, Romania, Latvia, Bulgaria, Lithuania, and Estonia experienced rates of credit expansion at levels above 30 percent, while Hungary, Poland, and Czech Republic recorded relatively moderate credit expansion (Figure 2). We find that a distinctive feature of many (but not all) countries in this group is the heavy reliance on foreign funding during the pre-crisis period. Notably, in countries like Latvia, Lithuania, Estonia, and Hungary, the contribution of foreign borrowing to credit growth was even larger than that of domestic deposits. Country specific effects aside, the growth in domestic deposits and real GDP growth were the other major determinants of credit expansion in the pre-crisis period. The decomposition of credit in the post-crisis period shows that retrenchment of foreign funding after the crisis was widespread and that most of the countries that relied heavily on such funding experienced the sharpest decline in credit growth. We also find that post-crisis slowdown in economic activity played a significant role in explaining lack of credit growth.

Figure 2. Decompostion of credit growth in EU emerging market economies
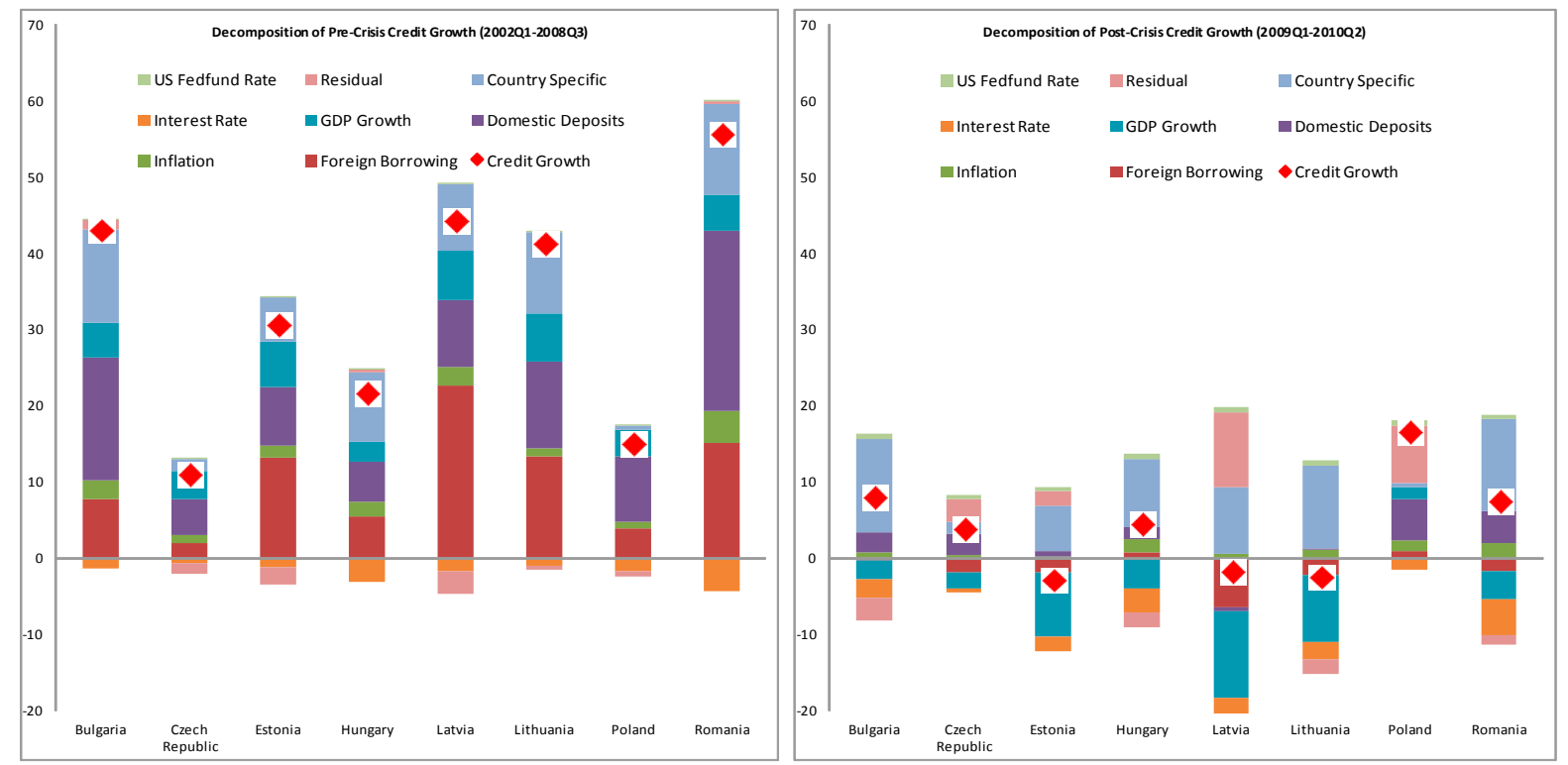

1/ Although the Czech Republic has been reclassified into the advanced economy group, we decided to include it in our sample as it was an EME during part of the period of our analysis. Source: Authors' calculations.

Next we look at the group of other European EMEs (Figure 3). Almost all countries in this group recorded double-digit average growth rates in the pre-crisis period, with Ukraine experiencing the highest credit expansion in the group (close to 60 percent). Also, in most countries of this group foreign borrowing constituted a major contributor to credit growth, but unlike in the EU EMEs, the contribution of domestic deposits in all cases was larger. In the post-crisis period, all countries experienced substantial slowdown in credit with both domestic deposits and foreign borrowing retrenching. Again, the role of economic decline was notable, particularly in Ukraine, Russia, Croatia and Georgia. 
Figure 3. Decompostion of credit growth in other European emerging market economies

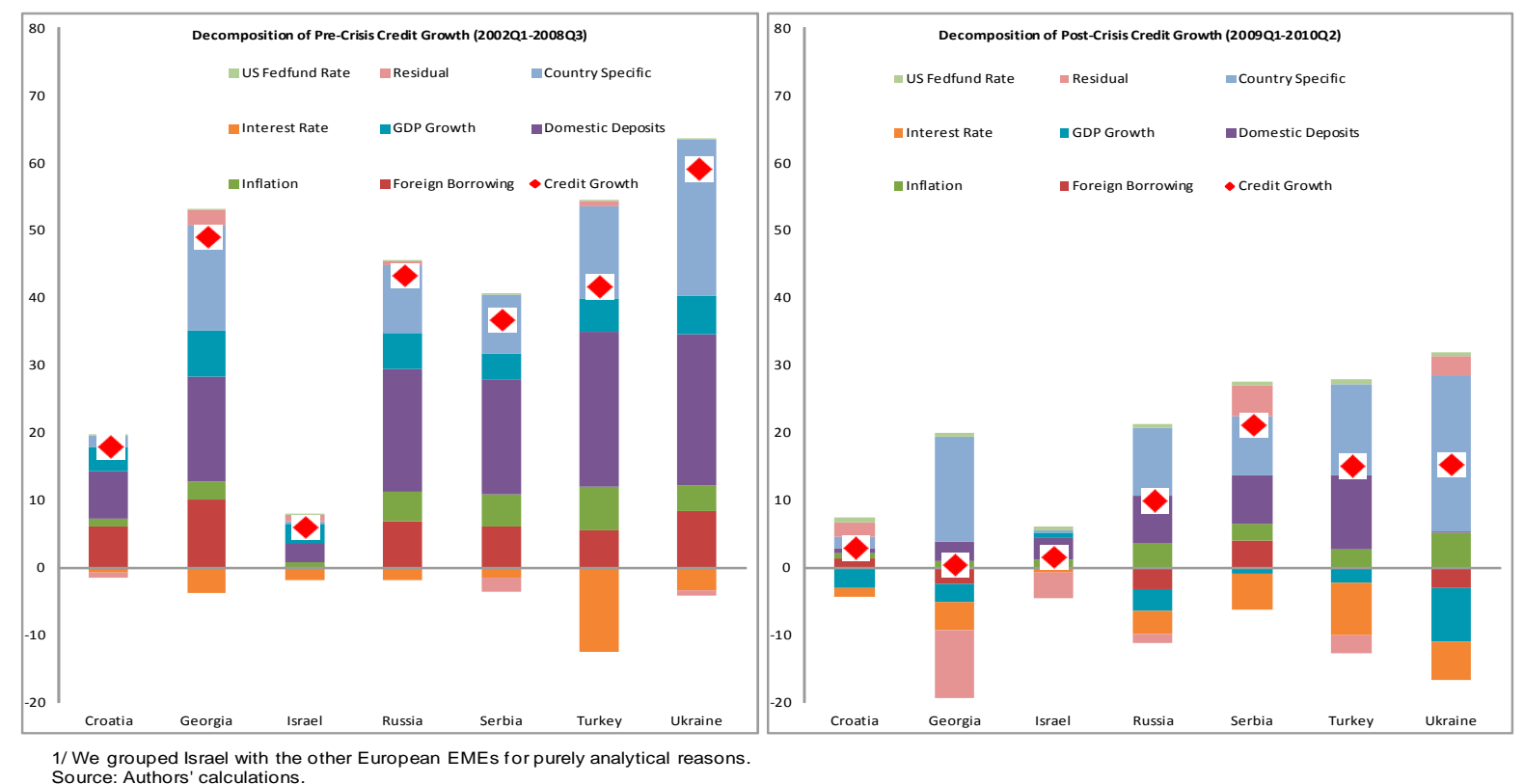

1/ We grouped Israel with the other European EMEs for purely analytical reasons.

In the group of Middle East and Africa EMEs, all four countries experienced solid credit expansion during the pre-crisis period (Figure 4). The expansions were driven largely by growing domestic deposit bases and economic growth. During the post-crisis period, all countries, except Morocco, recorded substantial slowdown in credit expansion, which was largely a result of economic slowdown and decline of contribution from domestic deposits. In the case of Jordan and South Africa, there was also some decline of contribution from foreign borrowings.

Figure 4. Decompostion of credit growth in Middle East and Africa emerging market economies

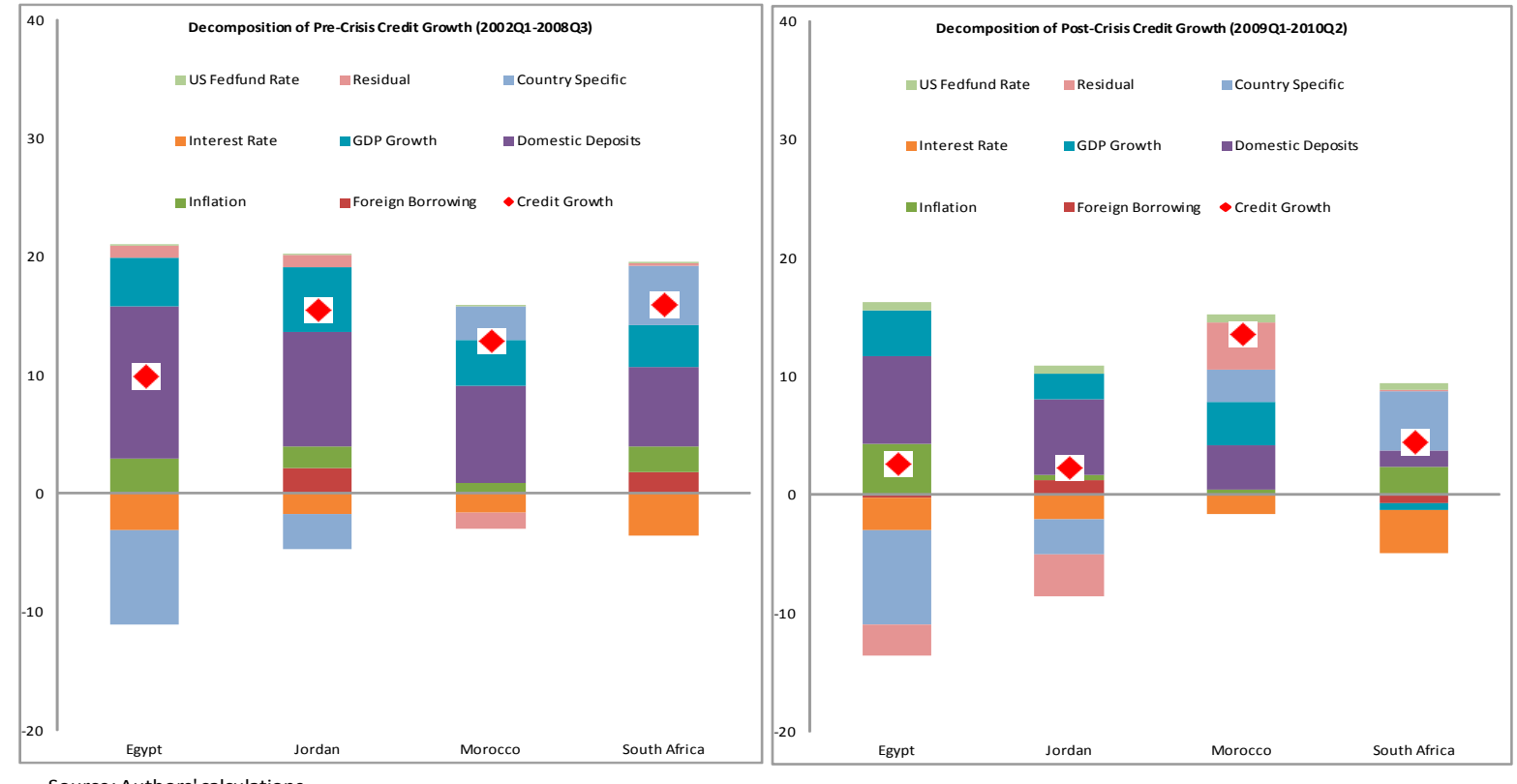

Source: Authors' calculations. 
Compared to the rest of the groups, the Asian EMEs group is a clear contrast (Figure 5). In the pre-crisis period there was a large variance in credit growth rates in the group, with Philippines, Thailand, Malaysia, and Korea experiencing relatively moderate credit growth, and Vietnam, Indonesia, and China recording credit growth in the range of 15 to 33 percent. It is in the post-crisis period that the contrast with other groups is the sharpest: China, Malaysia, and Philippines recorded acceleration in credit expansion and Vietnam more or less maintained its very high rate of credit expansion at above 30 percent. For most of the countries in this group, major determinants of bank credit, both pre- and post-crisis, were the domestic deposits and economic growth, although in Korea, Malaysia, and Philippines, foreign borrowing also played a role.

Figure 5. Decompostion of credit growth in Asia emerging market economies

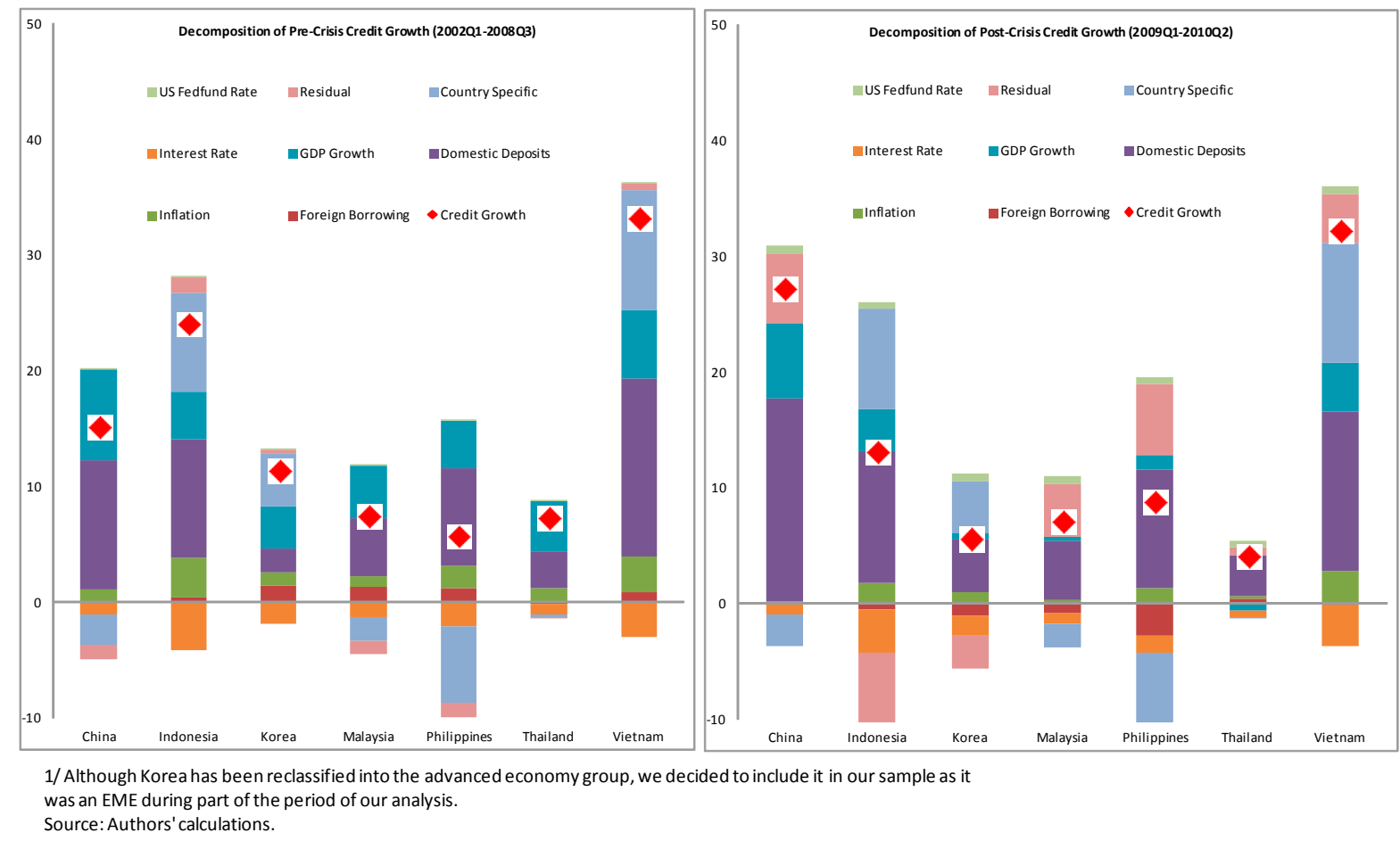

Turning to the Western Hemisphere, we first look at the Central American EMEs (Figure 6). In the pre-crisis period, all economies in this group experienced strong credit expansion, with Jamaica and Costa Rica on the high side at rates close to 30 percent, and Panama on the low side at a rate below 10 percent. In Costa Rica, Guatemala, and Mexico, major determinants of bank credit were the domestic deposits and economic growth, while in Jamaica and Panama foreign borrowings also played an important role. Unfortunately, due to lack of data, post-crisis decomposition was possible for only three of the five EMEs included in the group. As post-crisis decomposition shows, all three countries experienced a decline in the contribution of domestic deposits to credit growth. The contribution of foreign borrowing in Costa Rica and Jamaica turned negative, while in Mexico its role increased (suggesting Mexican banks were able to draw on foreign funding sources despite a difficult global environment). Also, the economic activity clearly provided negative contribution to credit expansion. 
Figure 6. Decompostion of credit growth in Central America emerging market economies

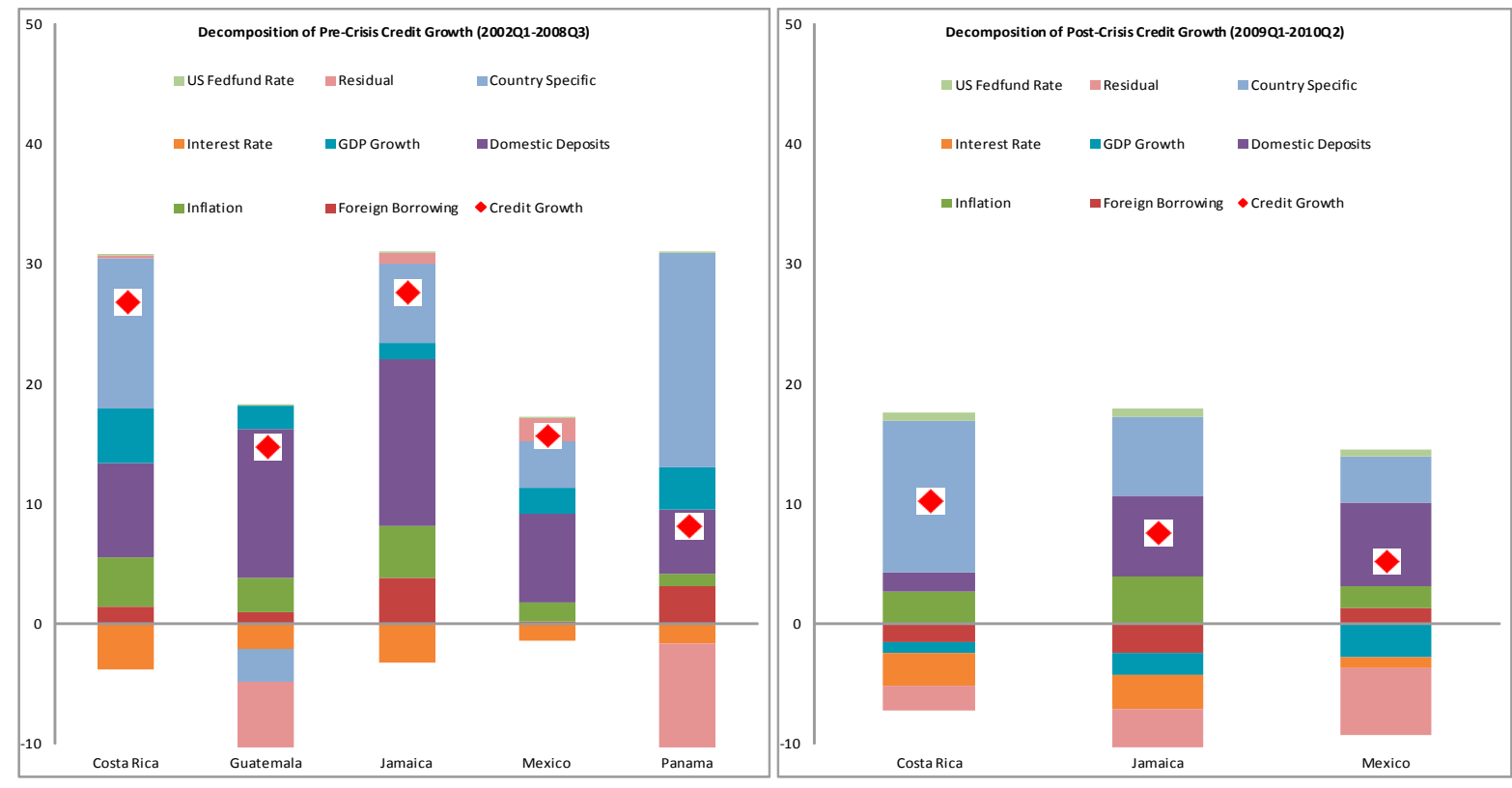

Source: Authors' calculations.

All South America EMEs, except Venezuela, experienced relatively moderate pre-crisis credit growth. The main determinants were domestic deposits and economic activity. It is interesting to note that in Argentina, foreign borrowing contributed negatively to credit growth even before the crisis. Post-crisis, all EMEs in this group, with the exception of Peru, experienced moderate slowdown in bank credit, which was determined mostly by a slowdown in domestic deposits and economic activity.

Figure 7. Decompostion of credit growth in South America emerging market economies
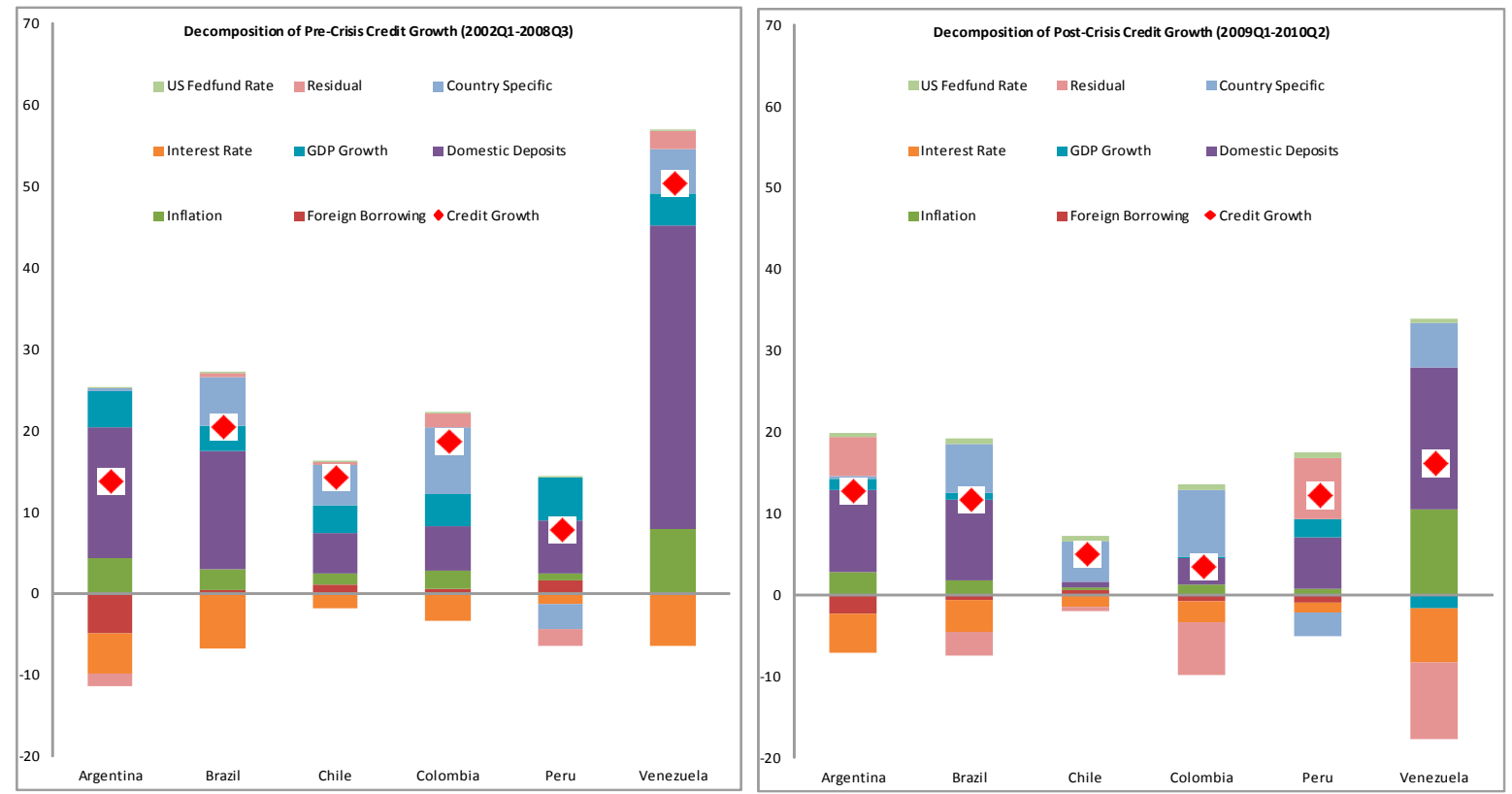

Source: Authors' calculations. 
Several policy lessons can be learned from our analysis. ${ }^{11}$ First of all, foreign capital is a mixed blessing for credit growth in EMEs. Countries that relied more heavily on foreign borrowing to finance domestic credit, notably some European EMEs, in general experienced the largest swings of credit growth before and after the crisis, while countries that relied less on foreign borrowing, e.g. EMEs in Latin America and Asia, fared much better during the crisis. Given the volatility of capital flows to EMEs, a banking sector that is dependent on foreign capital for funding may prove vulnerable to external shocks and could also be prone to boom-bust cycles. Therefore, macro-prudential policies should be particularly vigilant to foreign-capital fueled credit booms, which could reverse course very quickly. Second, building a robust domestic deposit base could be a key for sustained and stable credit growth. As is evident from our analysis, countries that experienced little or no deceleration of credit growth during the crisis were all supported by relatively robust/stable domestic deposit growth. Third, strong growth and low inflation are conducive to credit growth. Therefore, policies that improve fundamentals and lower inflation are not only beneficial on their own right; they could also boost credit growth and hence further strengthen economic activity. Last but not least, the health of the banking sector also matters: a banking sector with a healthy balance sheet is desirable for not only financial stability, but also credit growth.

\footnotetext{
${ }^{11}$ It should be noted that there are larger residuals in many cases during the post-crisis period. Also, there are significant heterogeneities across countries and our regressions are about the average behavior in the sample. This suggests that estimation results should be treated with caution.
} 


\section{Appendix: Pre-Crisis Sample Regressions}

Table 1. Regression Results under Alternative Specifications in Precrisis Period 1/

\begin{tabular}{|c|c|c|c|c|c|c|c|}
\hline \multirow[b]{2}{*}{$\begin{array}{l}\text { Deposit growth } \\
\times \text { deposit/credit }\end{array}$} & \multicolumn{7}{|c|}{ Private credit growth (2002Q1-2007Q4) } \\
\hline & $\begin{array}{l}0.439 * * * \\
(0.0807)\end{array}$ & $\begin{array}{l}0.456^{* * *} \\
(0.0802)\end{array}$ & $\begin{array}{l}0.418^{* * *} \\
(0.0769)\end{array}$ & $\begin{array}{l}0.251^{*} \\
(0.128)\end{array}$ & $\begin{array}{l}0.446^{* * *} \\
(0.0817)\end{array}$ & $\begin{array}{l}0.436^{* * *} \\
(0.0771)\end{array}$ & $\begin{array}{c}0.144^{*} \\
(0.0797)\end{array}$ \\
\hline $\begin{array}{l}\text { Non-res liab growth } \\
\times \text { non-res liab/credit }\end{array}$ & $\begin{array}{c}0.551^{* * *} \\
(0.125)\end{array}$ & $\begin{array}{c}0.550^{* * *} \\
(0.125)\end{array}$ & $\begin{array}{c}0.563^{* * *} \\
(0.131)\end{array}$ & $\begin{array}{l}0.512^{* *} \\
(0.201)\end{array}$ & $\begin{array}{c}0.560^{* * *} \\
(0.126)\end{array}$ & $\begin{array}{c}0.561^{* * *} \\
(0.130)\end{array}$ & $\begin{array}{c}0.734^{* * *} \\
(0.174)\end{array}$ \\
\hline Inflation & $\begin{array}{c}0.485 \\
(0.328)\end{array}$ & $\begin{array}{c}0.370 \\
(0.337)\end{array}$ & $\begin{array}{l}0.592^{*} \\
(0.346)\end{array}$ & $\begin{array}{c}0.121 \\
(0.406)\end{array}$ & $\begin{array}{c}0.537 \\
(0.340)\end{array}$ & $\begin{array}{c}0.472 \\
(0.360)\end{array}$ & $\begin{array}{c}0.347 \\
(0.336)\end{array}$ \\
\hline Lagged GDP growth & $\begin{array}{c}1.121 * * * \\
(0.367)\end{array}$ & $\begin{array}{c}1.279 * * * \\
(0.309)\end{array}$ & $\begin{array}{c}1.180^{* * *} \\
(0.350)\end{array}$ & $\begin{array}{c}0.139 \\
(0.451)\end{array}$ & $\begin{array}{c}1.152^{* * *} \\
(0.364)\end{array}$ & $\begin{array}{c}1.328^{* * *} \\
(0.299)\end{array}$ & $\begin{array}{l}-0.164 \\
(0.445)\end{array}$ \\
\hline Lagged deposit rate & $\begin{array}{l}-0.380 \\
(0.245)\end{array}$ & $\begin{array}{l}-0.650^{*} \\
(0.323)\end{array}$ & $\begin{array}{l}-0.418^{*} \\
(0.242)\end{array}$ & $\begin{array}{c}-3.105^{* * *} \\
(0.707)\end{array}$ & $\begin{array}{l}-0.444^{*} \\
(0.250)\end{array}$ & $\begin{array}{c}-0.677^{* *} \\
(0.309)\end{array}$ & $\begin{array}{c}-1.759 * * * \\
(0.436)\end{array}$ \\
\hline Change in fed fund rate & $\begin{array}{c}0.369 \\
(0.583)\end{array}$ & $\begin{array}{c}0.228 \\
(0.558)\end{array}$ & $\begin{array}{c}0.476 \\
(0.570)\end{array}$ & $\begin{array}{c}0.174 \\
(1.160)\end{array}$ & & $\begin{array}{c}0.329 \\
(0.538)\end{array}$ & $\begin{array}{c}-2.779 * * * \\
(0.934)\end{array}$ \\
\hline Change in exchange rate & & $\begin{array}{l}0.139 * * \\
(0.0551)\end{array}$ & & & & $\begin{array}{l}0.135^{* *} \\
(0.0542)\end{array}$ & $\begin{array}{c}0.308 \\
(0.192)\end{array}$ \\
\hline Lagged credit-to-GDP ratio & & & $\begin{array}{l}-0.134^{*} \\
(0.0745)\end{array}$ & & & $\begin{array}{c}-0.123 \\
(0.0785)\end{array}$ & $\begin{array}{c}-0.723^{* * *} \\
(0.167)\end{array}$ \\
\hline Lagged NPL ratio & & & & $\begin{array}{l}-0.853 \\
(0.740)\end{array}$ & & & $\begin{array}{l}-0.242 \\
(0.734)\end{array}$ \\
\hline US M2 growth & & & & & $\begin{array}{c}0.327 \\
(0.472)\end{array}$ & & \\
\hline Constant & $\begin{array}{l}3.215^{*} \\
(1.763)\end{array}$ & $\begin{array}{l}4.574^{*} \\
(2.412)\end{array}$ & $\begin{array}{l}9.220 * * \\
(3.779)\end{array}$ & $\begin{array}{c}38.41^{* * *} \\
(9.716)\end{array}$ & $\begin{array}{c}1.249 \\
(2.859)\end{array}$ & $\begin{array}{l}10.03^{* *} \\
(3.727)\end{array}$ & $\begin{array}{c}71.13^{* * *} \\
(12.25)\end{array}$ \\
\hline Country fixed effect & Y & Y & Y & Y & Y & Y & Y \\
\hline Time fixed effect & $\mathrm{N}$ & $\mathrm{N}$ & N & $\mathrm{N}$ & $\mathrm{N}$ & $\mathrm{N}$ & $\mathrm{N}$ \\
\hline Observations & 756 & 756 & 756 & 270 & 756 & 756 & 270 \\
\hline Adjusted R-sq & 0.475 & 0.493 & 0.481 & 0.351 & 0.475 & 0.498 & 0.529 \\
\hline
\end{tabular}

Source: IMF staff estimate.

1/ Standard errors are in parentheses and are clustered at country level. 
Table 2. Regression Results under Alternative Specifications in Precrisis Period with Time Dummies 1/

\begin{tabular}{|c|c|c|c|c|c|c|c|}
\hline \multirow[b]{2}{*}{$\begin{array}{l}\text { Deposit growth } \\
\times \text { deposit/credit }\end{array}$} & \multicolumn{7}{|c|}{ Private credit growth (2002Q1-2007Q4) } \\
\hline & $\begin{array}{l}0.444^{* * *} \\
(0.0765)\end{array}$ & $\begin{array}{l}0.459 * * * \\
(0.0758)\end{array}$ & $\begin{array}{l}0.391 * * * \\
(0.0676)\end{array}$ & $\begin{array}{l}0.260^{*} \\
(0.139)\end{array}$ & $\begin{array}{l}0.444^{* * *} \\
(0.0765)\end{array}$ & $\begin{array}{l}0.407^{* * *} \\
(0.0668)\end{array}$ & $\begin{array}{c}0.133^{*} \\
(0.0745)\end{array}$ \\
\hline $\begin{array}{l}\text { Non-res liab growth } \\
\times \text { non-res liab/credit }\end{array}$ & $\begin{array}{c}0.522^{* * *} \\
(0.124)\end{array}$ & $\begin{array}{c}0.513^{* * *} \\
(0.124)\end{array}$ & $\begin{array}{c}0.506^{* * *} \\
(0.131)\end{array}$ & $\begin{array}{l}0.496 * * \\
(0.208)\end{array}$ & $\begin{array}{c}0.522^{* * *} \\
(0.124)\end{array}$ & $\begin{array}{c}0.497^{* * *} \\
(0.132)\end{array}$ & $\begin{array}{c}0.749 * * * \\
(0.179)\end{array}$ \\
\hline Inflation & $\begin{array}{c}0.437 \\
(0.369)\end{array}$ & $\begin{array}{c}0.309 \\
(0.389)\end{array}$ & $\begin{array}{c}0.641 \\
(0.388)\end{array}$ & $\begin{array}{l}0.0671 \\
(0.523)\end{array}$ & $\begin{array}{c}0.437 \\
(0.369)\end{array}$ & $\begin{array}{c}0.512 \\
(0.408)\end{array}$ & $\begin{array}{c}0.370 \\
(0.419)\end{array}$ \\
\hline Lagged GDP growth & $\begin{array}{c}1.119 * * * \\
(0.385)\end{array}$ & $\begin{array}{c}1.283^{* * *} \\
(0.330)\end{array}$ & $\begin{array}{c}1.173 * * * \\
(0.382)\end{array}$ & $\begin{array}{l}0.187 \\
(0.497)\end{array}$ & $\begin{array}{c}1.119 * * * \\
(0.385)\end{array}$ & $\begin{array}{c}1.336^{* * *} \\
(0.333)\end{array}$ & $\begin{array}{l}-0.276 \\
(0.478)\end{array}$ \\
\hline Lagged deposit rate & $\begin{array}{l}-0.336 \\
(0.288)\end{array}$ & $\begin{array}{l}-0.621 \\
(0.373)\end{array}$ & $\begin{array}{l}-0.376 \\
(0.284)\end{array}$ & $\begin{array}{c}-3.002^{* * *} \\
(0.652)\end{array}$ & $\begin{array}{l}-0.336 \\
(0.288)\end{array}$ & $\begin{array}{l}-0.659^{*} \\
(0.357)\end{array}$ & $\begin{array}{c}-1.578^{* * *} \\
(0.495)\end{array}$ \\
\hline Change in fed fund rate & $\begin{array}{c}0.428 \\
(0.789)\end{array}$ & $\begin{array}{c}0.605 \\
(0.743)\end{array}$ & $\begin{array}{c}1.247 \\
(0.823)\end{array}$ & $\begin{array}{l}-0.103 \\
(1.101)\end{array}$ & & $\begin{array}{l}1.418^{*} \\
(0.798)\end{array}$ & $\begin{array}{c}-3.321^{* * *} \\
(1.043)\end{array}$ \\
\hline Change in exchange rate & & $\begin{array}{l}0.151^{* *} \\
(0.0557)\end{array}$ & & & & $\begin{array}{l}0.150 * * * \\
(0.0525)\end{array}$ & $\begin{array}{c}0.324 \\
(0.192)\end{array}$ \\
\hline Lagged credit-to-GDP ratio & & & $\begin{array}{c}-0.318^{* * *} \\
(0.117)\end{array}$ & & & $\begin{array}{c}-0.316^{* *} \\
(0.117)\end{array}$ & $\begin{array}{c}-0.867^{* * *} \\
(0.194)\end{array}$ \\
\hline Lagged NPL ratio & & & & $\begin{array}{l}-0.879 \\
(0.893)\end{array}$ & & & $\begin{array}{l}-0.0213 \\
(0.827)\end{array}$ \\
\hline US M2 growth & & & & & $\begin{array}{l}0.0423 \\
(0.969)\end{array}$ & & \\
\hline Constant & $\begin{array}{c}19.43 * * * \\
(2.519)\end{array}$ & $\begin{array}{c}21.16^{* * *} \\
(3.109)\end{array}$ & $\begin{array}{c}57.34^{* * *} \\
(14.04)\end{array}$ & $\begin{array}{c}41.15 \\
(26.63)\end{array}$ & $\begin{array}{c}18.01 * * * \\
(4.116)\end{array}$ & $\begin{array}{c}58.85^{* * *} \\
(13.39)\end{array}$ & $\begin{array}{c}134.1^{* * *} \\
(28.06)\end{array}$ \\
\hline Country fixed effect & Y & Y & Y & Y & Y & Y & Y \\
\hline Time fixed effect & $\mathrm{Y}$ & $\mathrm{Y}$ & Y & Y & Y & Y & $\mathrm{Y}$ \\
\hline Observations & 756 & 756 & 756 & 270 & 756 & 756 & 270 \\
\hline Adjusted R-sq & 0.789 & 0.797 & 0.798 & 0.880 & 0.789 & 0.807 & 0.917 \\
\hline
\end{tabular}

Source: IMF staff estimate.

1/ Standard errors are in parentheses and are clustered at country level. 


\section{REFERENCES}

Aisen, Ari and Michael Franken, 2010, "Bank Credit During the 2008 Financial Crisis: A Cross-Country Comparison,” IMF Working Paper 10/47 (Washington: International Monetary Fund).

Bakker, Bas and Anne-Marie Gulde, 2010, "The Credit Boom in the EU New MemberStates: Bad Luck or Bad Policies?” IMF Working Paper 10/130 (Washington: International Monetary Fund).

Barajas, Adolfo, Ralph Chami, Raphael Espinoza, and Heiko Hesse, 2010, "Recent Credit Stagnation in the MENA Region: What to Expect? What Can Be Done?” IMF Working Paper 10/219 (Washington: International Monetary Fund).

Barajas, Adolfo, Giovanni Dell’Ariccia, and Andrei Levchenko, 2007, “Credit Booms: The Good, the Bad, and the Ugly,” (unpublished: International Monetary Fund).

International Monetary Fund, 2009, "Will International Banks Transmit the Global Credit Crunch to Latin American and Caribbean Countries?” in Regional Economic Outlook: Western Hemisphere, April 2009 (Washington: International Monetary Fund).

Kamil, Herman and Kulwant Rai, 2010, “The Global Credit Crunch and Foreign Banks’ Lending to Emerging Markets: Why Did Latin America Fare Better?” IMF Working Paper 10/102 (Washington: International Monetary Fund).

McGuire, Patrick, and Nikola Tarashev, 2008, "Bank Health and Lending to Emerging Markets,” BIS Quarterly Review (Basel: Bank for International Settlements, December).

Rosenberg, Christoph B., and Marcel Tirpák, 2008, “Determinants of Foreign Currency Borrowing in the New Member States of the EU," IMF Working Paper 08/173(Washington: International Monetary Fund).

Takáts, Előd, 2010, "Was it credit supply? Cross-border bank lending to emerging market economies during the financial crisis,” BIS Quarterly Review (Basel: Bank for International Settlements, June). 